\title{
Competences and \\ Human Resources Empowerment in a Market-Driven Company. The Unilever Case
}

\author{
Giuseppe Varchetta*
}

\begin{abstract}
The organization of modern economy is struggling with its structural complexity. The intention of this article is to focus on the role assumed by the competencies method' in reference to development of human resources and its management in Market-Driven organizations. The application of such objective will be discussed afterwards by analyzing 'the competencies method' in multinational companies.

In the Unilever case, 'the competencies method' is supposed to delineate operative solutions concerning co-evolutionary relation between strategies and management development practices.
\end{abstract}

Keywords: Human Resources Management; Human Resources in MarketDriven Company; The Competencies Model; Management Responsibility; Unilever

'We have to convince ourselves that great and sublime art really exists [...] otherwise we will precipitate into despair'

T. Bernhard, 1985

\section{The Corporate System}

\subsection{Market-Driven Company and 'The Double Presence'}

The organization of modern economy is struggling with its structural complexity, impossible to simplify. As a result, such complexity regards also both: structure and practices of corporate system in terms of its operational and strategic activities (Weick 1969-79; Ceruti 1995; Bonazzi 2000).

\footnotetext{
*Human Resources Director, Unilever Italy (info@unilever.com)

Edited by: ISTEI - University of Milan-Bicocca

ISSN: $1593-0319$

Varchetta Giuseppe, Competences and Human Resources Empowerment in a Market-Driven Company. The Unilever Case, Symphonya. Emerging Issues in Management (symphonya.unimib.it), n. 2, 2000-2001, pp. 64-83 
Numerous observers called this phenomenon a 'change of the change' (Davis, Meyer 1998). Many formulations have been identified in order to describe such situation: globalization, new subjects, work transformation, gender revolution, ecology crisis and financial markets turbulence - they are conjoint challenges with a significant potential of unpredictability as numerous observers claim.

The intention of this article is to focus on the role assumed by the 'competencies method' in reference to development of human resources and its management in Market-Driven organizations. Such objective, application of which will be discussed afterwards by analyzing 'the competencies method' in multinational companies, leads to 'thin out' its possible interpretations and to choose introductive remarks regarding the trend. Such observations derive from the company experience system and its two structural components: the enterprise system and human resources system, both of them strictly related, complementary and repetitive.

Such selection requests, however, the identification of tendencies in both systems, in direct relation to cultural aspects of the competencies method; in other words, related to probable situations in context of corporate system. Such expectations serve for human resources managers to apply the competencies method in the competitive system, which drives operative and strategic choices of market-driven companies and identify vision, mission, dynamics and result expectations.

In order to gain understanding of the change that influences modern businesses, it is necessary to refer to another, greater changing process, commonly called 'modern era' defined also as 'post-modern' (Harvey 1989; Tourine 1992; Chiurazzi 1999). Such shift to 'post-modern' for the Corporate System may have two dimensions: external (in reference to globalization process) and internal (in reference to Fordist paradigm erosion).

When it comes to the globalization process it's necessary to refer, first of all, to the fact that physical and political barriers have lost the most of their economical importance. This means that the economy forces predominate over the political ones (Jean, Savona 1995; Beck 1997; Bauman 1998; Salimbeni 1999). Nowadays, we can observe that this process has weaken the fordist fundamentals, its ideas and organizational solutions, that since XIX century have always been vital for the organizational development of the companies from western countries (Rullani 1994; Halal 1994; Rullani, Vicari 1999).

This enormous change, easily identified in the companies operational practices, is rooted in so-called 'double presence' - a co-existence of corporate activities globalization and fordist model crisis. The 'double presence' concept puts a new light on the primary role of business - no longer limited to the production process as just few years ago, but enriched by the reproduction activity.

A fundamental role of businesses, however, has always been related to both: production and services activities. In fact, the primary role of production process is a function of various factors: organizational experience (characterized by a long and short-term planning), internal control and a strong conviction that procedures and corporate methodologies can help to achieve a sort of balance between real and estimated results. As a consequence, the emergencies tend to be ignored, like everything else which derives from the outside, is unknown and could influence the corporate decisions and processes.

In other words, the companies operate in a control prospective. Broadly speaking, the consumers as well as the distribution industries are represented and managed 
differently as far as they are determined by different external contexts. Naturally, this mutual relation should be intended according to the correspondence logic.

The environment (the external context), considered as a group of normative rules formalized by choices, decisions and firm actions, is in a control relation with a company services users system and with a distribution industry system. In fact, business becomes a supplier of optimal solutions, as a direct response to their clients problems. On the other hand, consumers and trade reactions to companies solutions influence significantly the way the businesses operate. Generally, companies tend to encourage such behaviors as a response to models developed interiorly, while the consumers and trade are called to learn more about the product or service in order to stimulate such reaction.

The companies experience, mainly focused on the manufacturing activity, becomes an experience of internal hyper-control, which tends to limit external relations as purely contractual and economical. Moreover, the supremacy of manufacturing activity brought to characterize economic cycles of the continuous development, where demand is in a regular growth and superior to supply, while the marketing methodology is successful only if based on 'one-way' communication methodologies.

The process of extension of corporate primary activities, known as a 'double presence', regards traditional manufacturing activity enriched by the reproduction one. Such process, however, shouldn't be considered as concluded but as a process in perpetual transition.

The production remains focal and fundamental for any of corporate activities: a focus on service and quality issues (Barassi 1988, Zeithaml 1990, Capranico 1992) - from few years extremely distinctive for western cultures and for consumer attitude in particular - requires, however, a step towards 'reproduction', a process that, necessary to say, can't exist if not rooted in manufacturing activities.

The 'reproduction' process stands for a particular orientation of fundamental processes to activities, through which, demand of personalized products and services can be satisfied in an accurate, prompt and characterized manner. The uniqueness of such goods has never been so significant and the consumers creativity so involved in main processes. As a result, businesses reactions across the reproduction activities are no longer standardized just like the manufacturing activities, but are numerous and able to react to service and quality demand (Di Nallo 1998, Busacca 1999).

In other words, companies try to exploit 'spontaneous' capabilities of their consumers through reproduction activities, in order to react according to personal aspects that identify different social groups. In fact, the consumers are no longer taking part of a mass, basically anonymous and homogeneous, as far as they can be easily identified by modern corporate systems and, what's more, their different characteristics are recognized.

This transition is marked out by the autonomy perspective. The service suppliers accept and adapt the vision, according to which the definition of trade and consumers characteristics can't be conclusive nor complete. The management of suppliers business (cognitive system included) is therefore incomplete and, through direct experience, is oriented to study a hypothetical development of consumers and trade specific characteristics. Such policy is based on active and not passive attitude towards companies life-cycle. In other words, it presumes dynamism and knowledge interacting together. The service suppliers can encourage and influence consumers and trade systems, but it is impossible for them to form their evolution, 
as far as both systems generally preserve their autonomy. This means that consumers and trade industries self-organization is not necessarily linked to external influence. In fact, the service suppliers interaction margin is indefinable.

It's necessary to underline how the 'double presence' (which lies in a double primary activity) contributes to change the corporate symbolism. In fact, the reference point in case of manufacturing industry is its performance whereas in case of the reproduction, and its ability (Mayer 1995, Morelli 2000).

A performance refers to a repetitive action, predictable and deeply rooted in corporate standards; the ability on the other hand, is a result of actions oriented to understand and respect single personal identities in order to approach their expectations afterwards (Figure 1).

Figure 1: The Contemporary Organization

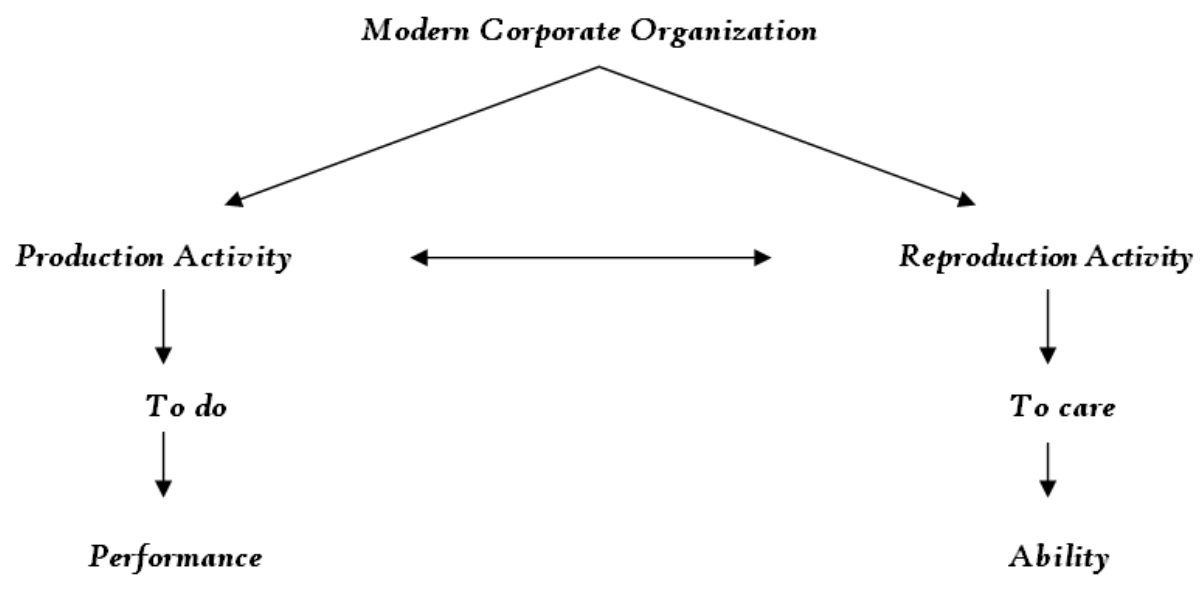

From macroeconomics point of view the 'double presence' concept meets companies in transition process, to be more precise - the shift from resources scarcity (basic assumption of Classical Economics) to markets in over-supply (New Economics assumption). As a result, all the companies have assisted in a progressive decentralization of 'resources combination efficiency', considered for long as a focal aspect of corporate organization, justified by the condition of scarcity. On the other hand, new conditions of over-supply set the centrality of customer satisfaction, as a measure of corporate competitiveness.

Some authors (Pine, Gilmore 1999) claim that such change is necessary for modern companies and they explain such shift across different stages of demand evolutionary model. A new 'value stage' can be described as 'all the reports that link, in a perpetual manner, consumers with all elements that surround them and influence their possibilities'. The 'value stage', as a situation, is formed by two elements: experience and transformation. The experience stands for a relevance which the company tends to involve the consumer with. On the other hand, the transformation is simply a value added related to a specific consumption experience and, as a consequence, deeply rooted in consumers behavior change. Market-driven companies are called to face the challenge generated by the condition of over-supply which involves new forms of demand. 


\subsection{The Reason and the Emotion}

The companies functioning, undoubtedly digitalization-driven, has always been oriented mostly on intellectual resources considered strategic in a value generation chain. As a consequence, intangible assets, experience, all the know-how system owned and progressively managed by the business, are necessary resources for business to keep its competitive force (Blancero, Boroski, Dyer 1996; Butera 1997; Edvinson, Malone 1997; Stewart 1997, Callieri 1998; Davenport, Prusak 1998, Ghoshal, Bartlett 1998; Accornero 2000; Como, Lizanbri 2000).

A state of hyper-competition presumes continuous confrontation between different corporate systems (D'Aveni 1994, Slywotzky, Morrison, Andelman 1998). What's more, the extension of primary activities by the reproduction process originated the primacy of human resources intellectual capabilities and skills ('mind-set' orientation), as fundamental for value generation chain. Such resources, called 'value makers' in order to underline their centrality and importance, concern skills such as creativity, achievement, relationality, active reaction, attention as well as simple capability of managing stumbling situations (Quaglino 1997; Pievani, Varchetta 1999; Davis, Meyer 1998, 2000).

The latent risk of such momentous transition concerns underestimation of holistic operative significance, imposed by new conditions, regarding strategic and executive competence.

As a consequence, such 'mind-set' orientation becomes a strategic component of 'value making process' and involves 'psychological factors' in corporate relations management. What's more, psychic characterization of the organizational experience leads to revaluation of human factor, no longer partial and insignificant. In other words, it occurs to value and to manage emotional variables, undoubtedly less known than rational ones, in respect to new competitive challenges, characterized by conditions of uncertainty and poor predictability. Therefore, such 'emotional variables' are retained an irreplaceable aspect of 'new' human reason and no longer a 'magical' driver of human behavior (Simon 1983; Kelly 1994; Ratti 1999).

Figure 2: The Underestimation Risk of the Intangible Assets

The underestimation risk
Of the intangible assets
Of the human capital
Of the know-how system
The "missed recognition" risk related to the need of:
emotion
astonishment
amazement
acceptance
ambiguity


A competitive challenge, that submitted and will continue to submit corporate systems of market-driven companies, is getting always more characterized by unsustainable hyper-competitiveness. In such context, rational interpretation of human intelligence seems definitely reductive and blind for other aspects which are less measurable, but certainly not less important in value generation chain (Figure 2).

\section{The Human System}

Exactly opposite to conditions derived from Taylor's theories applied willingly till late ' $80 \mathrm{~s}$, is the contemporary business context where individuals have to struggle with a network of experiences characterized by multiple doubts that 'spring' from complexity and instability of the new context.

The 'sociological frames' imposed by modern companies, enclose 'new individuals' in corporate structure - a change that required new interpretation of modern society, as far as the companies operate in its systems.

We all feel 'disoriented' inside and outside corporate systems, a first sign of radical modernity. In correspondence to growing freedom of action inside and outside the company we can observe growing condition of uncertainty aside from industry typology, which means that such dubiousness involves all: private individuals and professionals systems where the company operates (Beck 1994, 1997; Bauman 1998, 1999). From different points of view, we assist in an uncontrolled, unwanted, but not for that less intensive, process of order erosion of 'classic' modernity. A consequent theory of 'risk society' (Beck 1986) is gradually replacing operative indications of welfare state (Bagnasco 1999) and, on the other hand, in reference to company system, is forgetting 'lifelong one company' model, according to which both: training and carriers development are standardized and easily predictable. A 'risk society' is a fruit of speeding predomination of economic and financial themes over the political ones. From microeconomics systems point of view such concept is heavily contrasted by the company itself, as far as it compels the personnel to make decisions towards its professional carriers evolution with maximum of flexibility. This 'professional biography' seems to walk hand in hand with a 'strong personality' notion, which emphasizes the importance of uniqueness. Both concepts, however, seem a tribute to an excess anthropology.

The human resources operating in post-fordist systems are clearly subjected to new challenges, for which staff finds accurate expressions in terms of the way they handle with assets like time and work experience. Moreover, such solutions, in some respects, are highly paradigmatic.

- Time: numerous observers emphasize remarkable stress that is put on 'time fluidification' (Russo 2000, Brondoni 2000), in other terms - a conjoint pressure on rapidity and time-dimension, which, in turn, is no longer measurable (time digital). In fact, such phenomenon has generated new operative conditions for companies, completely extraneous for them till few years ago. 'The e-economy, no longer tied by the limits of time or space, confirms in a definitive manner that 1) time, is a primary competitive asset in modern companies 2) managerial capabilities connected to time-based management form intangible assets, which in turn are integrated with manufacturing process in terms of knowledge acquired and transmissible 3) 
time-management optimization reveals a significant connection with intangible assets like corporate culture, information systems, brand equity. [...] Moreover, the time valorization can be linked to philosophies and to oriental martial arts ('Choose the way and the moment to react quickly') and it prefigures: a) a selection of critical information b) a time selection of the intervention and critical phases specification c) a selection of the right moment.' It's necessary to underline that such 'new time orientation' is, in any case, heterogeneous respect to other human practices.

- Space: speaking in metaphors - 'no-place' - 'if a place can be defined through its relations with assets like identity, relations, history, a no-place can't be defined towards the same variables. According to our theory, 'new modernity' prefigures no-places creation (from anthropological point of view) which is in a heavy contrast with Baudeler's 'modernity' theory concerning antique places (considered and promoted as a 'memory place') that occupy circumscribed and specific space.' In fact, a post-fordist company is no longer a place, but rather a no-place considering the difficulty of managing all the doubts and confusion towards the industry and the company itself. Respect to hallowed fordist company - extremely delimited, closed to 'strangers' and carefully managed - the contemporary company is characterized by a co-evolution (Valdani 1997, Ceruti, Lo Verso 1998), which means that it is open to everyone, an 'everybody's place' where the exchange occurs according to a predefined scheme towards other "noplaces'. These 'no-places', therefore, are somewhat troubled by space instability. Such condition of unbalance reveals the human beings' autonomy and give his decision power back, on the other hand however, it generates a sense of confusion (Berto 1998).

\subsection{Modern Human Subject and Undetermined Identity}

A behavior of human subjects nowadays, inside and outside the corporate system, is characterized by a 'reflective modernization' (Beck, Giddens, Lasch 1994, 1996). This notion regards the capability of human subjects to reflect on the risk, uncertainty, contingency as a direct response for soaring crisis of the institutions but also for limits deriving from ungovernable character of the risk.

We can observe 'normal biographies' transforming into: 'choices biography', 'reflections biography', 'do-it-yourself biography'. Such shift leads directly to 'reflective modernization' in both: woman and man operating in post-modern economy.

We can struggle, however, with numerous difficulties that, with all their ambiguity, characterize modern times, to be more specific - the transition from holistic sociology to 'players sociology', an expression of global complexity par excellence. It is possible to recognize a remarkable drift towards 'constructive subject' that through self-determination and autonomy in terms of planning, leads to free society development model.

\footnotetext{
$\square$ '... the unique context where it is possible to achieve a balance between an instrumentalization and identity, technique and symbolism, is a personal life planning, in other words, the desire of us all to exceed merely kaleidoscopical experiences, discontinuous reactions to different forces occurred within a society. The ambition of following concept is
} 
to contrast personality 'laceration', that is to mobilize personal experience and culture in terms of certain economic and technical activities. As a consequence, the aim is to shape individual paths, 'bricked' with various situations, to be more precise, events that respect maximum of consistency and coherence. The unique propulsive force then, logically related to continuous, uncontrollable changes of the context, lies in individuals tension referable to the value assigned to personal experiences in terms of 'player's' profile construction. The effort of becoming a 'player', and not merely an 'individual', I use to call 'subject' ... the unique subjects goal is to self-construct' (Touraine, 1996).

If our society, purely market-oriented, can stimulate individuals to manage their affairs with a maximum of involvement and to make them feel responsible for their personal identity as human subjects, it must be also possible to draw conclusions regarding some regressive aspects of empowerment. In fact,

'while the stress put on the necessity to abandon the condition of minority and to adopt greater responsibility in reference to individual's destiny is the same, completely different is the way such individuals act. This attitude instead of encouraging greater participation and copartnership, promotes valorization of extremely strong individualist instinct and unconditional confidence in intuition' (Piccardo, 1995).

Such multiplicity and dissimilarity in terms of motivational variables guiding human subjects in modern corporate systems, can lead to profound identity crisis and consequently conducts to compromise institutional and individual objectives in an extremely revealing manner. 'What about a human subject that can't isolate himself, constantly disturbed by altering forces, which in turn constitute an inconvenience generator rather than a guarantee of 'attendance'? What about his identity? What about his decisions and his actions?'.

$$
\text { *** }
$$

Human Resources department in market-driven institutions is called to face numerous problems concerning internal and external contexts, institutional and individual as well, characterized by complexity and ambivalence basically unshakable.

\section{Human Resources Managers as a Guarantee of Correct Service}

\subsection{Tendencies in Human Resources Management Functions: The Italian Case}

Numerous tendencies have been recently underlined in reference to HR senior management function, all of them willingly described in countless essays (Camuffo 2000).

A service extension (Costa 1997) and further adoption of internal marketing culture towards the whole 'market' of workers operating in the corporate system (Boldizzoni, Nacamulli 1993) mark a preeminent evolutional tendency: the service concept introduced with all its potential of change by the HR senior management 
brings, along the supplier-client line, the concreteness in terms of real operative needs, reviewed accurately by human resources in every-day corporate activities.

The most relevant evolutionary tendency in terms of corporate culture claims that 'HR senior management as progressively expert and well-informed about business functioning. Such trend can be easily connected to an attempt of increasing a sense of responsibility among workers, or, as a general rule, among all the subjects operating in the corporate system'. In market-driven companies HR management is called to contribute directly, with no mediation, to business issues with a capability of immediate alignment of both: know-how and corporate culture to strategic factors, as well as to operative activities, directly dictated by the context in which the company operates.

In Italy, however, such tendency doesn't seem completely aligned with rules and suggestions traced by different researches.

In fact, recent studies (Boldizzoni 1999, Boldizzoni, Manzolini 2000) concerning the presumption that 'the function of HR management is strictly 'reaction-oriented' and it struggles with problems like coherent alignment of corporate policies with environment in continuous transformation and, on the other hand, with strategic and organizational assets evolution' have confirmed such theory.

In particular, recent studies allow to:

- Claim that 'the contribution of HR management in strategies delineating is mostly retained relevant even if such tendency is facing a certain fall.'

- Underline that 'corporate strategies seem totally oriented on effectiveness, efficiency and innovation, while the objectives and HR policies tend to greater caution and conservatism. In fact, such situation seems to support the theory mentioned previously, that is- basic hypothesis concerning unstoppable reaction-orientation and, secondarily, HR management problems with facing the matter of development and HR valorization. Obviously, human resources in this case are called to react to new business logic and corporate strategies (characterized by growing innovation and change rate) with appropriate policies and HR management tools.'

\subsection{A Possible Development Line of HR Senior Management}

The same Author who indicates new tendencies in personnel functions emerging from most representative essays, emphasizes (as possible development lines respect to HR senior management ambiguity confirmed by both: Italian case and recent researches) a decentralization of HR typical functions to advantage of new comprehension of HR activities. Such shift is, indeed, focal for market-driven companies in order to face new challenges (Camuffo 2000).

A model of deliverables (value or service) in relation to $\mathrm{HR}$ functions was proposed in 1997 by Ulrich. According to Ulrich, deliverables are all the services that must be guaranteed by HR senior management (Figure 3). Moreover, these services, after being defined, bring to indicate all the personnel functions afterwards. 
Figure 3: The Intangible Assets Model Extension

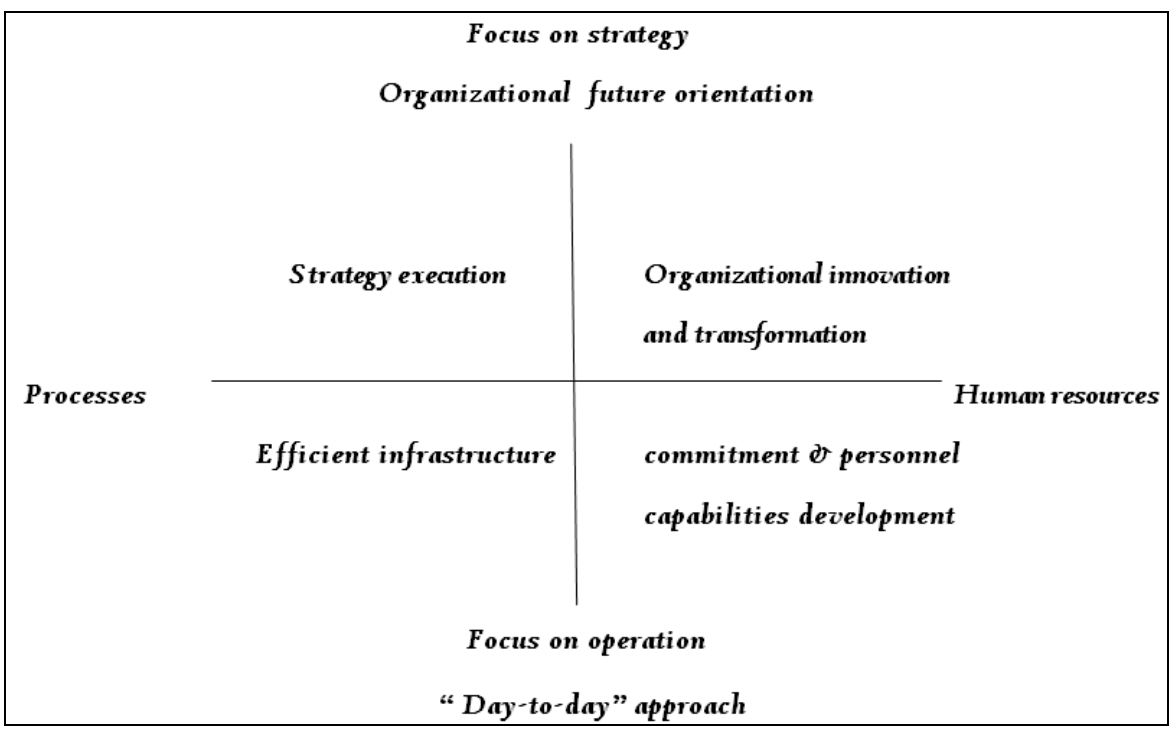

Source: Ulrich 1997; Camuffo 2000

The Figure 3 is based on two variables: time orientation (short-term - mainly operative and long-term - mainly strategic) and possible activities orientation (the way both: processes and human resources are managed).

According to Ulrich it is possible to identify four possible HR management keyfunctions (Figure 4), focused respectively on:

- organizational transformation and innovation;

- commitment and both: male and female skills development;

- efficient corporate infrastructure management;

- strategic human resources management.

Figure 4: The HR Management Functions Matrix

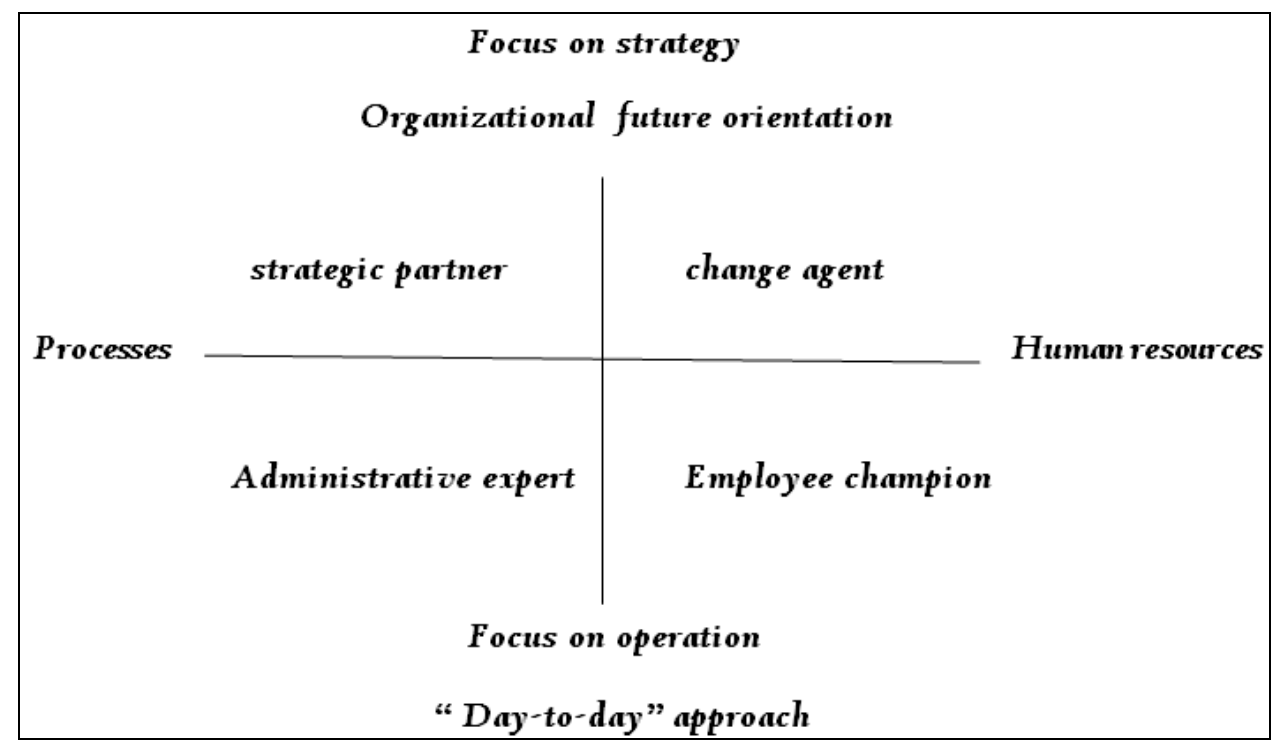

Source: Ulrich 1997; Camuffo 2000 
The competencies method then, represents a sort of a guide-line in order to find a way out from a strictness of certain activities respect to HR management possible functions. 'In fact, the fallowing model permits to interpret different approaches concerning competencies in relation to deliverables to follow and furthermore in relation to a role of human resources functions.

The ambition of the following article is to reflect on active competencies method adaptation by pointing out and by overcoming (across conjoint innovation) all the difficulties related to modern human subjects identity, to be more precise - the identity of subjects operating in market-driven systems. Moreover, such reflection regards also a state of uncertainty towards HR management functions. A union of both ambiguity areas - the first, concerning motivations of males and females operating in market-driven companies and the second, concerning HR management possible functions - can lead actually to disembedding process. In fact, 'social relations are always characterized less by the proximity and more by a distance. Our actions, on the other hand, are always more liable to an ungovernable and unknown factors, just like their consequences in the long-run'.

The following essay is oriented against any kind of individual or institutional relief of responsibility of HR management subsystem, a phenomenon related and powered by disembedding processes. This hypothesis can be explained as follows: HR management, particularly careful with services development (deliverables) rigorously in coherence with market-driven perspective, undertakes its role through an effective identification and creation of activities that would provoke a sense of responsibility among males and females operating in the corporate system. The sense of responsibility, to be more precise, regards individual objectives in terms of personal career development and, as a consequence, also corporate objectives. Moreover, such spirit can lead to concrete and powerful competence method application. In particular, a psychological aspect is taken into consideration, that is'best performers' specification. The 'best performers' figure can help with understanding the ambiguity of modern operative contexts and, what's more, their output (all the competencies applied by individuals) structures all internal workactivities and becomes a reference point in training processes.

In reference to organizational activities, the competencies method across the 'best performer' figure, presents concrete examples of growing 'sense of responsibility' among workers leading consequently to better work-performances. The 'responsibility' attitude establishes a strong link between individuals (operating in equivocal contexts, hardly analyzable and characterized by continuous emergencies) and their jobs and expected outputs.

\subsection{The Responsibility Concept: Evolution Remarks}

Operative experiences and researches ascribable to organization developmentdriven interventions in accordance with competencies method application in various contexts (Del Lago 2000) have proved the accuracy of some assumptions regarding corporate sense of responsibility. To be more precise, such responsibility concept may be facilitated throughout all the organization experiences as well as all the activities that fuels 'the competencies model'.

Generally, the responsibility is considered as a sense of anxiety of individuals (or group of individuals) operating in the corporate system towards hypothetical consequences of their actions in view of expanding uncertainty. 
The competence itself is hardly conceivable. In fact it can be seen in 'defined undefined' prospective. To be more precise, all the corporate actions are moved exactly by the enigmatic character of competence 'undefinability' (Gargani 1999). Beyond this, we can only analyze the execution, performance and reactions to expected behaviors in view of previous estimation accuracy (Morelli 2000). The enigma, with its inestimable power of attraction and with its capability to draw attention, delineates the action - a thriving aspect of corporate behavior. On the other hand, it provides numerous suggestions and remarks which, however, have to consider 'undefinability' margins and leave space to individuals 'astonishment'. Nevertheless, such amazement and organization undefinability don't involve a lack of operative rigorousness, but a strong belief that competences are emerging properties expressed by individuals in specific situations. Such situations can't be just simplified by an average as far as they are specific, unique and highly defined in terms of time and space (Ratti 1998; Morelli 2000).

Through these experiences, favored and powered by the competencies method, individuals operating in corporate system can relate to particular organization activity. In fact, a link between work and both: men and women is based on their capability to reflect - fundamental for responsibility concept (Beck, Giddens, Lasch 1994).

A relation is a key-situation towards the responsibility. In fact, it revives only in operative actions, which theory links individuals with organizational structures. Such relation between a subject and organization is perfectly circular. 'The 'action theory' then, requires a draft of a 'process' conception that involves all the subjects and considers the 'time' as a fundamental corporate driver. An 'action' is a term which (in social sciences key) indicates a link between an 'agent' and subjective and objective sense. It means that the 'action theory' requires a 'decision theory', in other words- an analytical element of action. In reference to corporate organization, both - 'action' and 'decision' conceptions are highly oriented on individuals and relational structures they continuously generate and regenerate. It's obvious that according to this theory, it becomes impossible to consider an organization as over-ordered or simply isolated from individuals'.

According to diverse operational experiences and human sciences interpretations (Leccardi 1999; Jedlowski 1999; Bauman 1999; Carmagnola 2000) a human subject, highly absorbed by every-day activities and struggled by unpredictable character of his competencies, is strictly convinced that in times of increasing liberty and dubiousness the unique certainty regards the inalienable nature of the responsibility (Bauman 1999).

The origins and development of this point of view are rooted in an active character of interpretative practices, according to which an unpredictable portion of competencies lays on 'organizing actors', perfectly supported by new management methodologies and by organizational development.

Various observers notice a significant change in a 'responsibility culture'. In their opinion, the responsibility is considerably distant from general ethical standards but also from a 'duty' culture as a fundamental reference to social life. A modern culture then, puts a new light on the 'responsibility' matter, 'which is no longer considered as a quality of action nor of the subject himself, but rather a link between an agent and his actions'. Moreover, from ethical point of view, men and women nowadays are heterogenic norms-free and highly absorbed by their every-day activities that involve different emotions and endemic uncertainty. As a consequence, individual responsibility assumption becomes an essential step forward. 
An auto-reflection on our experience lead us to consider a responsibility as 'a process through which we take note of experiences we are living in order to understand its sense'. The competencies method solicit the action and pushes both: men and women towards 'obligatory relationality' with their work. Moreover, this sense of relation encourages individuals to reflect on their experiences and, as a consequence, to expand their organizational sense of responsibility.

The competencies method facilitates the attention towards all the events, stimulates auto-reflection process but also generates a remarkable inclination to relationality. The following features can be recognized as distinctive competencies which play their part in 'responsibility' concept up-date.

Considering the end-less discussion about HR management role in reference to Market-Driven companies, operative indications we've seen previously seem extremely significant in front of the identification mechanism change, from overpowering corporate models to weaker ones.

The identities considered stable in the past are crumbling in front of progressive mother-institutions deterioration as well as evolution of new social relations conditions, characterized by a frequent 'in/out' approach rooted in general, reduced predictability of organization development mechanisms (individual and collective). The following identities move towards an endemic temporariness at the expense of identification processes.

Figure 5: Organization and Identification Models Evolution

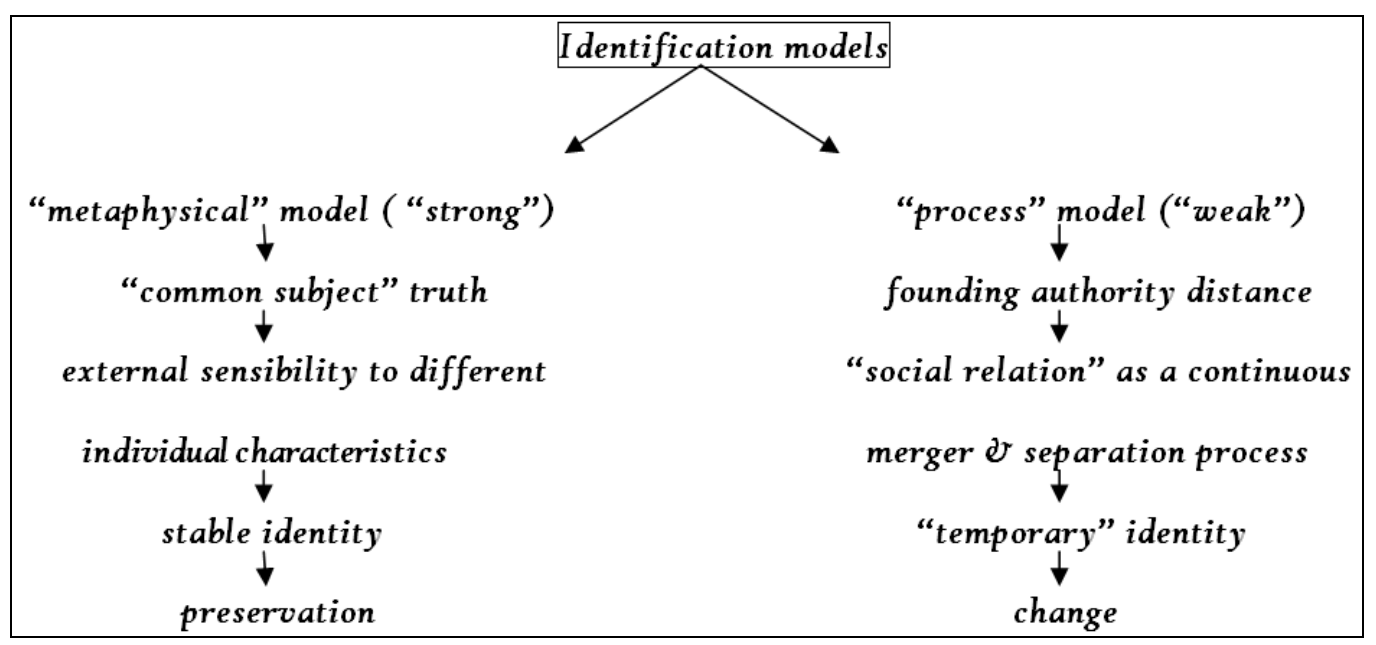

The condition of temporary precariousness reveals a new HR management role which, as we said previously, puts a new light on relation between an actor and his action. In fact, the competencies method application, if accurately conceptualized, can bring to individual responsibility adaptation inside the corporate system. It's necessary to say that the following personal commitment leads consequently to new collective responsibility interpretation (Weick 1995). 
Figure 6: New HR Management Role

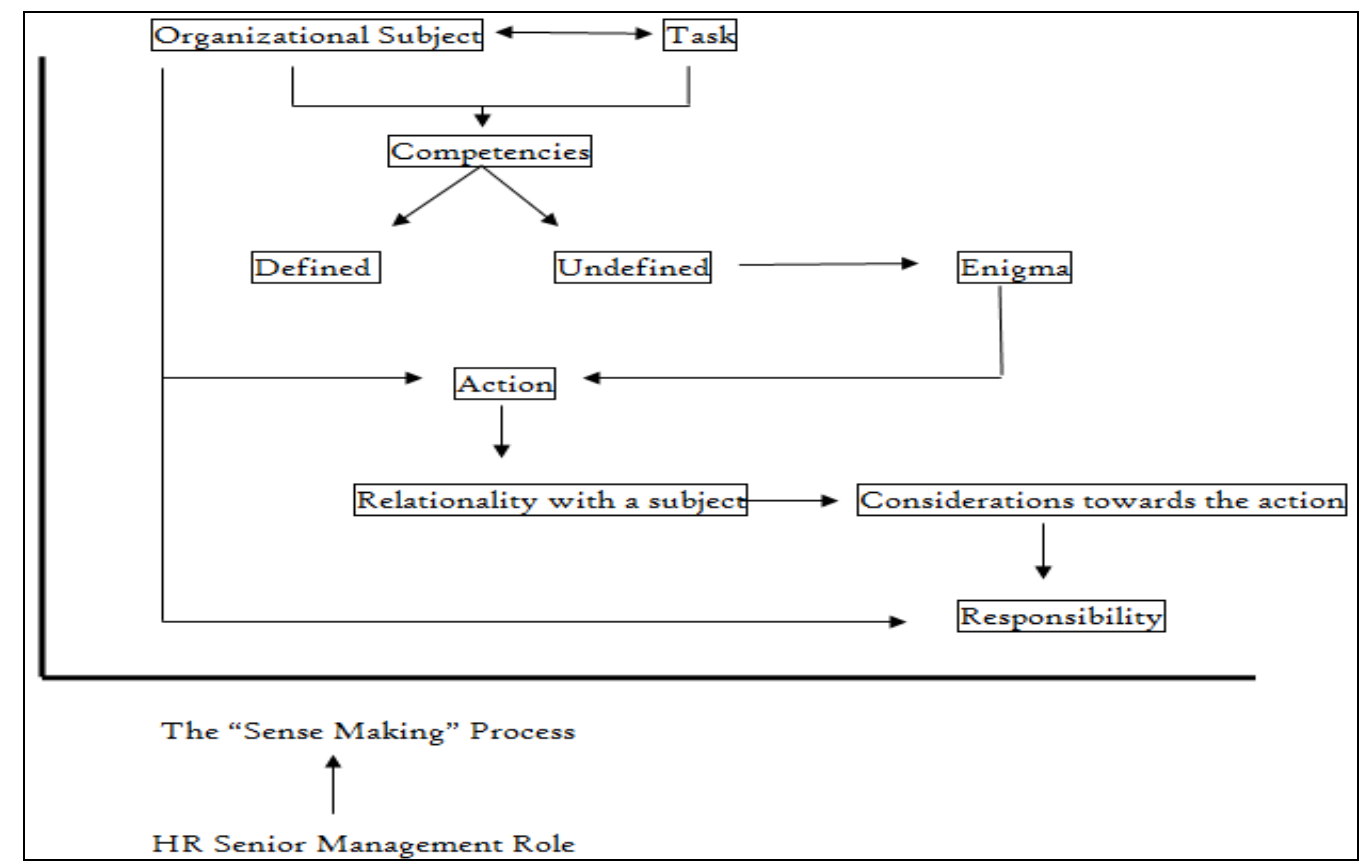

\section{The Unilever Case}

The ambition of the following study case is to describe a multinational company experience in competencies method application on the operative field.

- The company operates from very beginning in consumer goods industry on a worldwide scale. It's leader position is particularly strong in European markets, even if the company operates in all the markets in the world. It's distinctive and particular effort in terms of marketing, management development and notorious advances in technology (supported by focusing strategies and careful brand equity management) enabled Unilever to handle the crisis in the late ' $80 \mathrm{~s}$ and early ' $90 \mathrm{~s}$ generated by hard discount expansion (Brondoni 2000). In mid '90s the company had to face both: new competitiveness (and consequently new hyper-competitiveness models) and confrontation with financial markets in reference to new economy expansion (D'Aveni 1994; Rampini 2000).

- Unilever face new competitive challenge also by greeting new management development approach centered on the competencies method application in its practices. It is necessary to say that the company deals with MD systems change according to holistic approach. It encloses a complex relation between an organizational actor and his organizational reality in a systemic vision, articulated in three essential aspects (Figure7):

- Organizational analysis point of view in reference to different job contents (job value) in terms of responsibility and value added.

- Managers personality aspects correlated to competencies profile deriving from best performer research (differentiating competencies).

- All the professional capabilities, fundamental for certain functional activities (professional skills). 
- The competencies method offers different methodologies to use (Ratti 1992, 1999; Oggioni, Rolandi 1988; Camuffo 2000; Capucci 2000; Sandberg 2000; Varchetta 2001; Rossi 2001). In this case, as we noticed previously, the reference point is a best performer figure retained perfectly coherent with business strategies and with global context of Unilever operative activities. It's necessary to underline that the best performer allows an orientation of management development.

\section{Figure 7: HR Management Model}

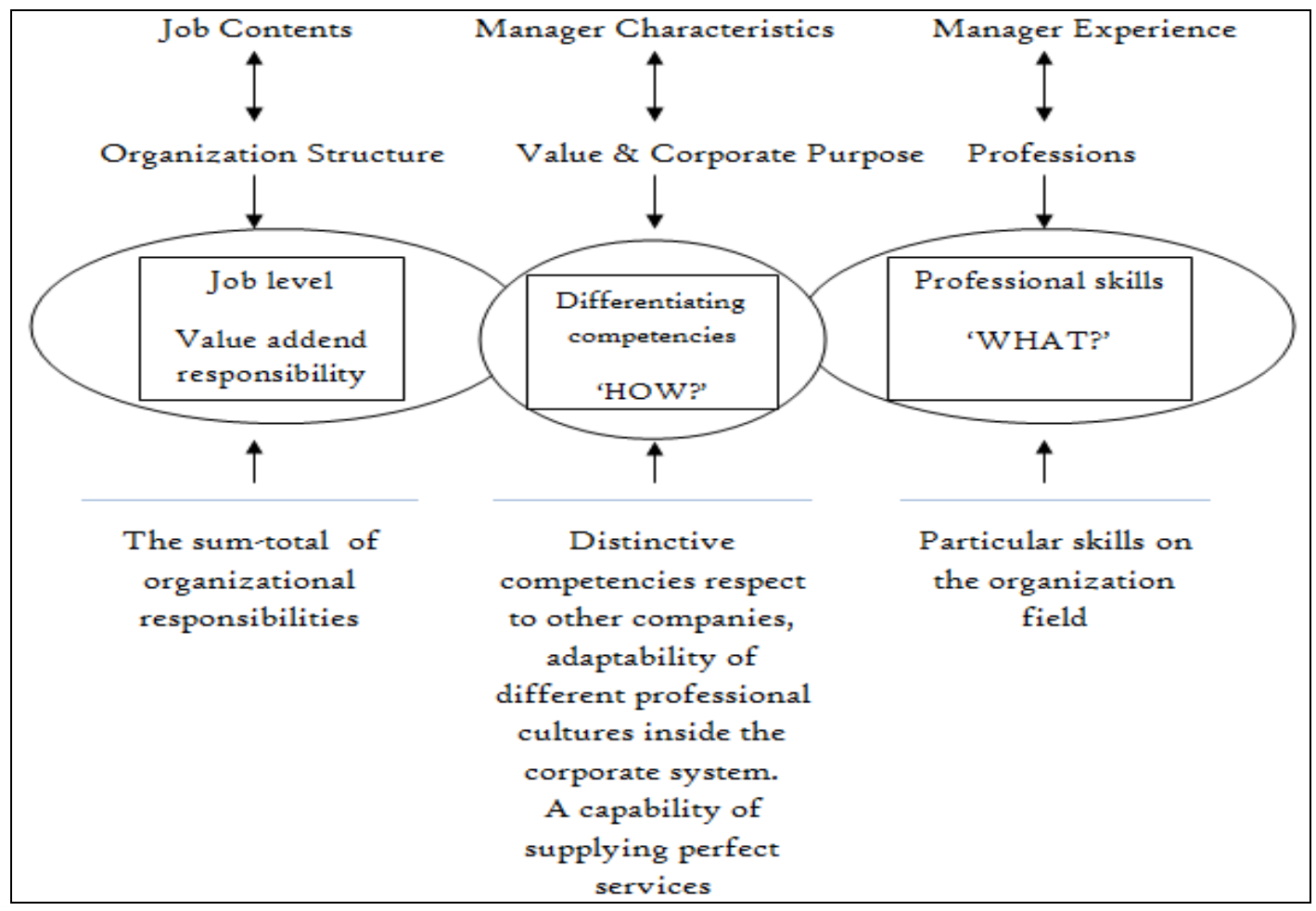

- On one hand it transforms numerous management practices and personnel development into diffused process of organizational learning (Argyris, Schon 1969-96; Carmagnola 2000; Morelli 2000). Such phenomenon occurs due to a diffusion of the best performer competencies over the corporate managers and secondly over other employees.

- On the other hand it allows to maintain a recursive relation between the strategy evolution and management development practices, in other words between a context and human subject (Ceruti, Lo Verso 1998). It is possible thanks to continuous monitoring of best performer competencies evolution, as far as they facilitate understanding and foreseeing of the corporate strategies dynamics.

- The new management development strategy based on the competencies method application can be divided in two phases (with a 5 years of gap between each other) which are strictly related to the corporate strategy.

The first phase reflects over business strategy oriented on efficiency recover and identifies 11 competencies.

- Clarity of purpose: regards situations taken as a whole; it perceives what and how is necessary to be realized. 
- Practical Creativity: demonstrates mental agility; evolves new business ideas reportable to new possible activities.

- Objective analytical power: evaluates in an accurate manner which activities have to be done, also in difficult and complex conditions.

- Market orientation: takes seriously into consideration external (society, consumers, technology) and internal contexts evolution.

- Entrepreneurial Drive: oriented on business performance improvement in short and long term. It is related to initiatives which are often retained hazardous and, as a consequence, require a remarkable perseverance.

- Leading others: stimulate other colleagues to obtain better results, also in terms of innovation.

- Developing others: skills and competencies development linked to a coherent actions coordination. It generates opportunities of development and growth for other activities.

- Influencing others: a capability to influence (in a positive manner) colleagues, clients and consumers aside from the position occupied in corporate hierarchy.

- Self confident integrity: a capability to defend own values and beliefs, but also to take difficult decisions.

- Team commitment: an active engagement in team objectives retained superior to personal ones.

- Learning from experience: a capability of learning from own (and colleagues) successes and mistakes.

In the first phase of competencies method application a focus is put on competencies related to individuals psychological balance, organization relationality and HR development and management. It is clear that this issue is oriented on a prompt efficiency recover.

After the first phase (usually after four years) of competencies method application, companies have to aim at business development. Such strategic requirement leads to competencies model adjustment $\left(2^{\text {nd }}\right.$ phase $)$ in reference to new conditions and strategic challenges (Figure 8).

\section{Figure 8}

\begin{tabular}{|c|c|}
\hline 1996 & 2000 \\
\hline EFFECTIVE MANAGER & LEADERSHIP GROWTH PROFILE \\
\hline - Entrepreneurial Drive & $\begin{array}{l}\text { - Passion for Growth } \\
\text { - Seizing the Future }\end{array}$ \\
\hline - Market Orientation & - Breakthrough Thinking \\
\hline - Leading Others & $\begin{array}{l}\text { - Holding People Accountable } \\
\text { - Empowering Others } \\
\text { - Team Leadership } \\
\end{array}$ \\
\hline - Developing Others & - Developing Others \\
\hline - Team Commitment & - Team Commitment \\
\hline $\begin{array}{l}\text { - Influencing Others } \\
\text { - Learning from Experience }\end{array}$ & $\begin{array}{l}\text { - Strategic Influencing } \\
\text { - Organizational Awareness }\end{array}$ \\
\hline
\end{tabular}

A company awareness of becoming always more market driven forced the management development system to orient the competencies method towards growth-driven and ethic-driven approach. Such commitment is explainable by 
objectives achievement - an aim followed willingly by both: the company (collective subject) and its managers (single subjects).

The 'results at any cost' culture leads market-driven companies to continuous revaluation of its management development practices. Moreover, these activities are supposed to conciliate objectives of both: the company and single human subjects. A capability of market-driven companies to reckon, valuate and satisfy firstly their internal market needs (in other words: needs of their co-workers at all levels) (Nacamulli, Boldizzoni 1993; Pievani, Varchetta 1999) seems the only way to satisfy the external market $\left(2^{\text {nd }}\right.$ market). Obviously it follows an authentic market-driven logic centered on co-evolutionary interaction with partners and consumers, and not only with financial markets (Valdani, Di Nallo 1998). The risk, however, concerns a possible relational instability between a strategy and management development practices. In fact, such activities should be aligned with an 'actual context review', which derives simply from organizational activities and from business strategy application in particular. Till today however, the competencies method application with a consecutive 'best performer' figure, permitted businesses to avoid such regression and to enforce corporate strategies and management development practices. The last one can be expressed by three fundamental characteristics:

- professional uniqueness of all the actors involved in the corporate system;

- impossibility to foresee in an exhaustive manner the role nature;

- necessity to contextualize the competencies method in every single case.

In the Unilever case the following model is at crucial point. The competencies method in this case, is supposed to delineate (in an exhaustive manner) operative solutions concerning co-evolutionary relation between strategies and management development practices. The following study-case, even though it recognizes a transitive character of the phenomenon, perfectly proves the importance of this relation as well as a significance of the intangibles applied in concrete managerial decisions. The risk management, despite being limited and imperfect, is definitely cognitive and action-oriented as a direct expression of the competencies method application.

\section{Bibliography}

Accornero A., Un secolo di lavoro, Next, n. 10, 2000.

Argyris Ch., Schön D., Apprendimento organizzativo, Guerini e Associati, Milan, 1998.

Augé M., Non luoghi, Eleuthera, Milan, 1993.

Bagnasco A., Tracce di comunità, Il Mulino, Bologna, 1999.

Barassi D., La service idea, Edizioni del Sole 24 Ore, Milan, 1988.

Bauman Z., Dentro la globalizzazione, Laterza, Bari, 1999.

Bauman Z., La solitudine del cittadino globale, Feltrinelli, Milan, 2000.

Beck U., La società del rischio, Carocci, Rome, 2000.

Beck U., I rischi della libertà, Il Mulino, Bologna, 2000.

Beck U., Che cos'è la globalizzazione, Carocci, Rome, 1998.

Beck U., Giddens A., Lasch S., La modernizzazione riflessiva, Asterios, Trieste, 1999.

Bernhard T., Antichi maestri, Adelphi, Milan, 1992. 
Berto G., Freud, Heidegger, Lo spaesamento, Bompiani, Milan, 1998.

Blancero D., Boroski J., Dyer 1., Key Competencies for a Transformed Human Resource Organization: Results on a Field Study, Human Resource Management, vol. 35, n. 3,1996.

Boldizzoni D., Nacamulli R.C.D., Il marketing interno dei servizi del personale, Sviluppo $e$ Organizzazione, n. 136, 1993.

Boldizzoni D., L'evoluzione della direzione del personale nelle imprese italiane, Sviluppo $e$ Organizzazione, n. 174, 1999.

Boldizzoni D., Manzolini L. (ed.), Creare valore con le risorse umane, Guerini e Associati, Milan, 2000.

Bonazzi G., Dire, fare, pensare, Angeli, Milan, 1999.

Boyatzis R.E., The Competent Manager: a Model for Effective Performance, Wiley, New York,1992

Brondoni S.M., Brand Policy and Brand Equity, Symphonya. Emerging Issues in Management (symphonya.unimib.it), n. 1, 2000-2001.

http://dx.doi.org/10.4468.2001.1.02brondoni

Brondoni S.M., Competizione accelerata, Il Sole 24 Ore, 08.05.2000.

Busacca B., Grandinetti R., Troilo G., Transizione del marketing e concezione evolutivo-sistemica del consumatore, E. Rullani, S. Vicari (ed.), Sistemi ed evoluzione nel Management, Etas, Milan, 1999.

Butera F., La transizione dal fordismo a una economia basata sulle organizzazioni e sul lavoro della conoscenza, Sociologia del Lavoro, n. 65, 1997.

Butera F., Verso un'economia basata sulla organizzazione e sul lavoro della conoscenza: sei tesi per la ricerca e l'azione, C. Callieri (ed.), Lavoro ed economia della conoscenza, Angeli, Milan, 1998.

Callieri C. (ed.), Lavoro ed economia della conoscenza, Angeli, Milan, 1998.

Camuffo A, Il valore delle competenze, Sviluppo e Organizzazione, n. 178, 2000.

Capucci U. (ed.), Business, strategia, competenze, Guerini e Associati, Milan, 1999.

Capranico S., In che cosa posso servirla, Guerini e Associati, Milan, 1992.

Carmagnola F., La specie poetica, Mimemis Eterotopia, Milan, 2000.

Cepollaro G.L., Dimensione individuale e dimensione organizzativa nell'analisi e nello sviluppo delle competenze, L. Dal Lago (ed.), Ricomporre, essere e fare, Guerini e Associati, Milan, 2000.

Chiurazzi G., Il postmoderno. Il pensiero nella società della comunicazione, Paravia, Turin, 1999.

Ceruti M., Lo Verso G. (ed.), Epistemologia e psicoterapia, Cortina, Milan, 1998.

Como E., Lizanbri A, (ed.), Sette pareri sul lavoro che cambia, Next, n. 10, 2000.

Costa G., Economia e direzione delle risorse umane, Utet, Turin, 1997.

Dal Lago L. (ed.), Ricomporre, essere e fare, Guerini e Associati, Milan, 2000.

D'Aveni R.A., Ipercompetizione, Edizioni del Sole 24 Ore, Milan, 1995.

Davenport T.H., Prusak L., Il sapere al lavoro, Etas, Milan, 2000.

Davis S., Meyer C., Blur: le zone indistinte dell'economia interconnessa, Edizioni Olivares, Milan, 1999.

Davis S., Meyer C., Il futuro della ricchezza, Angeli, Milan, 2000.

Di Nallo E., Quale marketing per la società complessa?, Angeli, Milan, 1998.

Gargani AG., Il filtro creativo, Laterza, Bari, 1999.

Ghoshal S., Bartlett C.A., The Individualized Corporation, Harper Collins, New York, 1997. 
Halal W.E., From Hierarchy to Enterprise. Internal Markers are the New Foundations of Management, Academy of Management Executive, vol. VII, n. 4, 1994.

http://dx.doi.org/10.5465/AME.1994.9412071706

Harvey D., La crisi della modernità. Una ricerca sulle origini del cambiamento culturale, Il Saggiatore, Milan, 1995.

Kelly K., Out of Control. La nuova biologia delle macchine, dei sistemi sociali e dell'economia globale, Urra Apogeo Libri, Milan, 1996.

Jedlowski P., Le trasformazioni dell'esperienza, C. Leccardi, Limiti della modernità, Carocci, Rome, 1999.

Leccardi C., Responsabilità e riflessività, C. Leccardi (ed.), Limiti della modernità, Carocci, Rome, 1999.

Leccardi C. (ed.), Limiti della modernità, Carocci, Rome, 1999.

Mayer R.C., Davis J.H., Schoorman F.D., An Integrative Model of Organizational Trust, Academy of Management Review, vol. 20, n. 3, 1995.

http://dx.doi.org/10.2307/258792

McClelland D.C., Testing for Competence rather than Intelligence, American Psychologist, n. 28, 1973.

http://dx.doi.org/10.1037/h0034092

Morelli U., Scienza senza oggetto, fenomeni ibridi e pratiche conoscitive scivolose: oltre gli approcci deterministici nello studio delle competenze, L. Dal Lago (ed.), Ricomporre, essere e fare, Guerini e Associati, Milan, 2000.

Oggioni E., Rolandi A, Performance Improvement. Il miglioramento delle prestazioni attraverso lo sviluppo delle competenze, Etas Libri, Milan, 1998.

Pagliarani L., Il coraggio di Venere, Cortina, Milan, 1985.

Piccardo C., Empowerment, Cortina, Milan, 1995.

Pievani T., Varchetta G., Il management dell'unicità, Guerini e Associati, Milan, 1999.

Quaglino G.P., Psicodinamica della vita organizzativa, Cortina, Milan, 1997.

Rampini F., La New Economy. La rivoluzione in corso, Laterza, Bari, 2000.

Ratti F., Le competenze di successo, Sistema Impresa, n. 4, 1992.

Ratti F., L'intelligenza emotiva, Sviluppo e Organizzazione, n. 171, 1999

Rossi A, Il bilancio di competenze, Sviluppo e Organizzazione, n. 182, 2001.

Rubbia S., Introduzione a Pine Il B.J., Gilmore J.H., L'economia delle esperienze, Etas, Milan, 2000.

Rullani E., L'impresa 'reale' e le sue prospettive: una mappa dell'evoluzione in corso, Economia, Finanza e Marketing, n. 24, 1994.

Rullani E., Vicari S. (ed.), Sistemi ed evoluzione nel Management, Etas, Milan, 1999.

Russo P., New Economy, New Human Kind, Il Mulino, n. 5, 2000.

Salimbeni A.P., Il grande mercato. Realtà e miti della globalizzazione, Bruno Mondadori, Milan, 1999.

Sandberg J., Interpretare le competenze, Sviluppo e Organizzazione, n. 182, 2001.

Savona P., Jean C., Geoeconomia, Angeli, Milan, 1995.

Simon H., La ragione nelle vicende umane, Il Mulino, Bologna, 1984.

Slywotzky AJ., Morrison D.J., Andelman B., La zona del profitto, Guerini e Associati, Milan, 2000.

Spencer L., Spencer S., Competenza nel lavoro, Angeli, Milan, 1995.

Stewart T., Il capitale intellettuale, Ponte delle Grazie, Firenze, 1999. 
Touraine A, Critica della modernità, Il Saggiatore, Milan, 1993.

Touraine A, Ricominciando dall'individuo, Micromega, n. 2, 1996.

Touraine A, Libertà, uguaglianza, diversità, Il Saggiatore, Milan, 1998.

Ulrich D. et al., Judge Me more by My Future than by My Past, Human Resource Management, Spring, 1997.

Valdani E., Dalla concorrenza all'ipercompetizione, dall'evoluzione alla coevoluzione, Economia $e$ Management, n. 3, 1997.

Varchetta G., Il metodo delle competenze, dall'evoluzione alla coevoluzione, Economia $e$ Management, n. 3, 1997.

Zeithaml V.A., Parassuraman A., Berry L.L., Servire qualità, Mc-Graw Hill Italy, Milan, 1991. 